3. Solovov A.V. E-learning: issues, didactics, technology / A.V. Соловов. - Samara: «New technology», 2006. - 462 p.

4. Fomina A.S. Blended learning in higher educational establishments: institutional, organizational, technological and pedagogical aspects [Electronic resource] / A.S. Fomina. - Access mode: teoria-practica.ru/rus/fi les / arhiv_zhurnala /.../ fomina.pdf.

DOI https://doi.org/10.30525/978-9934-588-80-8-1.67

\title{
ШЛЯХИ ВІДРОДЖЕННЯ ТА РОЗВИТКУ ПОЛЬСЬКОЇ ПЕДАГОГІКИ КУЛЬТУРИ НАПРИКІНЦІ ХХ СТ.
}

\author{
Шостачук Т. В. \\ кандидат педагогічних наук, \\ доиент кафедри образотворчого мистеитва та дизайну \\ Житомирський державний університет імені Івана Франка \\ м. Житомир, Украӥна
}

Метою роботи $є$ дослідження шляхів відродження педагогіки культури після падіння в XX столітті тоталітарного комуністичного режиму.

У 1989 році в країнах так званого «Східного блоку» наступив тріумф демократії й незалежності, який зумовив зміни й в Республіці Польща: розпочалася комплексна трансформація у сфері політики, економіки, науки. Також відбулися значні зміни в соціальній свідомості, культурі та освіті.

У польській педагогіці культури також відбулися кардинальні зміни, які вплинули на іiі розвиток, ідентичність та статус наукової дисципліни. Мова йде про широко зрозумілу педагогічну думку, яку, за Б. Шліверським, розуміють як належність до світу гуманістики, у межах якої знаходяться предмети гуманітарних досліджень [5, с. 42-44].

Нам імпонує думка Декана Люблінської Вищої Школи (Рики) доктора К. Южиста про те, що виправданою теоретичною основою системи освіти може стати педагогіка культури як субдисципліна гуманітарних наук. Тому варто, вважає вчений, будувати теоретичні основи польської освіти на грунті досягнень, започаткованих понад століття тому [2, с. 11-32].

На його думку, педагогіка культури усупереч початим, проте малоуспішним спробам вписати іiі в процес глибоких культурних i цивілізаційних змін, які відбуваються в Республіці Польща, все ж 252 
заслуговує на значно більшу увагу, ніж раніше. Педагогіка як наука про виховання, в широкому розумінні, шукає власну ідентичність в абсолютно новій соціально-економічній та культурній реальності [2, с. 11-32].

Найбільш точно діагностував ситуацію в польській педагогіці культури того часу професор Б. Суходольський: «Сучасний світ - писав він - характеризується особливо гострим посиленням кризи в суспільному баченні реальності як комплексу цінностей; цивілізація виявляється під загрозою і потребує реконструкції. Уперше, мабуть, стан педагогіки $є$ істотно підірваний, уперше, бо педагогіка й практика виховання втрачають стабільну точку опори» [6, с. 121].

Вагомий внесок у відродження польської педагогіки культури, на нашу думку, зробив професор Я. Гайда, який є учнем т.зв. варшавської наукової школи Б. Суходольського та І. Войнар, у сфері інтересів якої знаходяться питання виховання мистецтвом. Слід підкреслити, що характерною рисою польської концепції виховання мистецтвом є іiі тісний зв'язок із культурою та експонування освітнього аспекту.

На думку Я. Гайди, «складна сучасність з її непрозорою реальністю, сповненою неоднозначності та багаторазових численних загроз, спричинених глибокою кризою цивілізації та спробами подолання цієї ситуації, сприяє поверненню до ідеї педагогіки культури й вимагає водночас критичної оцінки іiі історичного доробку та сучасної інтерпретації філософсько-методологічних заснувань» [1, с. 5].

Під редакцією Я. Гайди у видавництві Університету Марії КюріСклодовської в Любліні в 1998 році була опублікована книга: «Педагогіка культури. Історичні досягнення, сучасні суперечки навколо культурної освіти, перспективи розвитку» (Pedagogika kultury. Historyczne osiagnięcia, wspótczesne kontrowersje wokót edukacji kulturalnej, perspektywy rozwoju), яка стала каноном публікацій у галузі педагогіки культури [1].

У цій праці зібрані матеріали двох наукових конференцій, організованих Кафедрою Теорії Поширення Культури Інституту Педагогіки Університету Марії Кюрі-Склодовської у Любліні в співпраці з Люблінським Відділенням Польського Педагогічного Товариства та під патронатом Комітету Педагогічних Наук Польської Академії Наук.

Перша конференція, організована у рамках співпраці кафедри Теорії Поширення Культури Інституту педагогіки, факультетом педагогіки та психології Університету Марії Кюрі-Склодовської та кафедрою дидактики Вищої Офіцерської Школи Повітряних Сил (5-6 грудня 1995 р., Демблін) проходила під гаслом «Про повернення до педагогіки культури» (O powrót do pedagogiki kultury). Матеріали конференції під 
назвою «Педагогіка культури та культурна освіта» (Pedagogika kultury a edukacja kulturalna) були опубліковані під науковою редакцією Я. Гайди в 1996 році.

Одна 3 ключових тез конференції належить С. Волошину «Педагогіка культури не потребує реституції - $\epsilon$ живою» (Pedagogika kultury nie wymaga restytucji - jest żywa), яку автор аргументує так: « класиків педагогіки культури. $€$ живою у своєму сучасному продовженні у вигляді культурної освіти. Вона жива, тому що досі основними та науково корисними $є$ базові категорії та концептуальні відмінності, на які спирається педагогіка культури та сучасна гуманістична філософія виховання» [8, с. 12-15].

Ще одна стаття, 3 не менш красномовною назвою, написана професоркою I. Войнар: «Тривала присутність педагогіки культури» (Trwała obecność pedagogiki kultury, 1998), що містить багато цінних коментарів щодо сутності розуміння педагогіки культури як об'єкта теоретичного дослідження та практичної діяльності. Важливо, що авторка згадує творців польської педагогіки культури Б. Наврочиньського, С. Гессена та Б. Суходольського. У праці І. Войнар погоджується $з$ думкою Б. Суходольського, що наука й техніка, нарівні 3 мистецтвом належать людям, виражають людей і творять людей, отже вони повинні становити основу сучасного виховання - виховання наукою, технікою та мистецтвом, а творча, мислездатна та чутлива людина $€$ творцем культури й одночасно ії творінням» [7, с. 16-25].

На другі конференції - «Педагогіка культури - новини й перспективи», організованій UMCS (26-27 червня 1997 р., Люблін) у співпраці з Осередком «Брама Гродська - Театр NN», був проведений грунтовний аналіз педагогіки культури, надана оцінка досягнень та окреслена перспектива іiі розвитку. Матеріали були опубліковані в збірнику «Педагогіка культури», виданого UMCS у м. Люблін в 1998 р. під редакцією Я.Гайди. Збірник статей став джерелом знань та обгрунтуванням тези про необхідність продовження вивчення сучасних досягнень педагогіки культури.

Ці дві конференції та їх публікації - перші наукові дискусії такого масштабу за останні кілька десятиліть в Польщі, предметом яких стали історичні досягнення, сучасність та перспективи розвитку педагогіки культури. Зазначимо, що саме тодішній завідувач кафедри Теорії Поширення Культури (Teorii Upowszechniania Kultury) Університету Марії Кюрі-Склодовської професор Я. Гайда став натхненником цього починання. У своїй науковій роботі він виявив незмінну вірність ідеям педагогіки культури, які були сформовані на польському грунті Б. Наврочиньським, С. Гессеном та Б. Суходольським. 
Отже, нині ми можемо спостерігати тенденцію «переоцінювання концепції педагогіки культури» [3]. У полі зору цієї концепції знаходяться не тільки конкретні теорії, що народилися на грунті педагогіки культури, але й ії досягнення, як джерело натхнень для роздумів над сучасними проблемами.

\title{
Література:
}

1. Gajda Janusz (red.), Pedagogika kultury. Historyczne osiągnięcia, współczesne kontrowersje wokół edukacji kulturalnej, perspektywy rozwoju, Wydawnictwo Uniwersytetu Marii Curie-Skłodowskiej, Lublin, 1998. S. 5.

2. Jurzysta Kazimierz. Pedagogika kultury w systemie współczesnej edukacji / Journal of Modern Science. Toм 4/35. 2017. S. 11-32.

3. Milerski B., Pedagogika kultury, [w:] Pedagogika, Z. Kwieciński, B. Śliwerski (red.), t. I, PWN, Warszawa, 2006. S. 223.

4. Pedagogika kultury a edukacja kulturalna. Rozwój historyczny, aktualność, perspektywy. Lublin-Dęblin, 1996. s. 395.

5. Śliwerski B. Współczesna myśl pedagogiczna. Znaczenia, klasyfikację, badania. Kraków: Oficyna Wydawnicza «Impuls», 2009. S. 42-44.

6. Suchodolski B. Uspołecznienie kultury. Warszawa, 1972. s. 199.

7. Wojnar I. Trwała obecność pedagogiki kultury, [w:] J. Gajda (red.) O nowy humanizm w edukacji, Kraków: Oficyna Wydawnicza «Implus»,1998. S. 16-25.

8. Wołoszyn S. Pedagogika kultury nie wymaga restytucji - jest żywa, [w:] J. Gajda (red.) Pedagogika kultury a edukacja kulturalna. Wydawnictwo UMCS-WSOSP, Lublin-Dęblin,1996. S. 12-15.

DOI https://doi.org/10.30525/978-9934-588-80-8-1.68

\section{ЗАСАДИ ГЕНДЕРНОГО ВИХОВАННЯ УЧНІВСТВА: ПОКАРАННЯ ТА ЗАОХОЧЕННЯ}

\author{
Шумська Д. І. \\ аспірантка кафедри педагогіки, \\ Криворізький державний педагогічний університет \\ м. Кривий Ріг, Дніпропетровська область, Україна
}

Європейська зорієнтованість розвитку України спонукає до значного оновлення вітчизняної системи освіти із урахуванням системи цінностей та принципів європейської спільноти. Ключовим у системі принципів існування демократичних держав $\epsilon$ принцип гендерної 